\title{
Pili on Gardnerella vaginalis studied by electronmicroscopy
}

\author{
YVONNE L. BOUSTOULLER, A. P. JOHNSON and D. TAYLOR-ROBINSON
}

Division of Sexually Transmitted Diseases, MRC Clinical Research Centre, Harrow, Middlesex HA1 3UJ

\begin{abstract}
Summary. Fourteen recently isolated strains and two laboratory strains of Gardnerella vaginalis were examined by electronmicroscopy for the presence of pili. All strains isolated recently from both men and women were heavily pilated. In contrast only a few pili were seen on organisms of the two laboratory strains, with many of the organisms having no pili. The importance of multiple subculture in this loss was supported by the observation that the degree of pilation of one freshly isolated strain decreased on repeated subculture. Other findings suggested that this was probably due to gradual loss of pili and not to selection of organisms that were non-pilate originally.
\end{abstract}

\section{Introduction}

Gardnerella vaginalis is a gram-negative coccobacillus which is found in the lower genital tract, particularly of women but also of men. The number of organisms of this bacterium isolated from the vagina of women with bacterial vaginosis is greatly increased in comparison with the number from healthy women (Spiegel et al., 1980, 1983) although their role in the pathogenesis of the disease is unclear.

In a previous study of G.vaginalis by electronmicroscopy, with negative staining (Johnson and Davies, 1984), some of the organisms were found to possess narrow pili. Three of the eight strains examined, however, appeared non-pilate. Moreover, in preparations of the five pilate strains, many non-pilate organisms were also seen. The relatively sparse pilation observed in that study may have been due to each of the strains having had multiple passages, albeit an unknown number, in medium in the laboratory. The current study, therefore, was undertaken to examine the expression of pili by G.vaginalis organisms that had been subcultured less than ten times after isolation and to determine to what extent passage in medium diminished pilation.

\section{Materials and methods}

\section{Bacteria}

Sixteen strains of G.vaginalis were studied (table). Four strains had been isolated in this laboratory from the

Received, 6 Jun. 1986; accepted, 15 Aug. 1986. vaginas of patients diagnosed as having bacterial vaginosis, six strains were from the vaginas of women who were 9-10 weeks pregnant and undergoing chorionic villous sampling, and four strains were from the urethras of men with non-gonococcal urethritis. Two strains (67-1 and $40 \cdot 1)$ that had been examined in the earlier study (Johnson and Davies, 1984) were re-examined.

All strains were isolated on human blood-tween 80 (HBT) agar (Totten et al., 1982) and were subcultured on Columbia blood agar (Difco). They were identified as G.vaginalis as described previously (Taylor and Phillips, 1983).

\section{Negative staining}

Bacteria were grown on Columbia blood agar at $37^{\circ} \mathrm{C}$ in an atmosphere of $\mathrm{CO}_{2} 5 \%$ in air for one or two days. Electronmicroscope grids were prepared according to the method of Henrichsen and Blom (1975), as modified previously (Johnson and Davies, 1984), and were examined with a Philips EM 300 electronmicroscope at $60 \mathrm{kV}$. A minimum of 40 organisms of each strain was examined and the degree of pilation of each organism was assessed subjectively by one observer (YLB) as follows: $++=$ pili radiating from $>25 \%$ of the periphery; $+=$ pili radiating from $1-25 \%$ of the periphery; $-=$ no pili seen. The diameter of the pili was measured from the electronmicrographs with an eyepiece graticule.

\section{Results}

All 14 recently isolated strains of G.vaginalis possessed pili (table). The extent of pilation differed among these strains, although no difference in expression of pili was seen between strains isolated from men and women. Organisms without any pili were not seen in 12 of the recently isolated strains 
Table. Degree of pilation of 16 strains of G.vaginalis

\begin{tabular}{|c|c|c|c|c|}
\hline \multirow[b]{2}{*}{ Strain } & \multirow{2}{*}{$\begin{array}{l}\text { Patient } \\
\text { category* }\end{array}$} & \multicolumn{3}{|c|}{$\begin{array}{l}\text { Percentage of bacteria with } \\
\text { indicated degree of pilation } \dagger\end{array}$} \\
\hline & & ++ & + & - \\
\hline 352 & BV & 82 & 18 & 0 \\
\hline 6916 & BV & 73 & 23 & 3 \\
\hline 762 & BV & 53 & 47 & 0 \\
\hline $194 \mathrm{P}_{4} \ddagger$ & BV & 78 & 22 & 0 \\
\hline $194 \mathrm{P}_{21} \ddagger$ & BV & 80 & 20 & 0 \\
\hline $194 \mathbf{P}_{40}^{\dagger}$ & $\mathrm{BV}$ & 26 & 74 & 0 \\
\hline 314 & CVS & 94 & 6 & 0 \\
\hline 908 & CVS & 91 & 9 & 0 \\
\hline 121 & CVS & 73 & 27 & 0 \\
\hline 815 & CVS & 59 & 41 & 0 \\
\hline 403 & CVS & 48 & 52 & 0 \\
\hline 214 & CVS & 33 & 75 & 3 \\
\hline 69 & NGU & 88 & 12 & 0 \\
\hline 153 & NGU & 86 & 14 & 0 \\
\hline 169 & NGU & 59 & 41 & 0 \\
\hline 72 & NGU & 39 & 61 & 0 \\
\hline $67 \cdot 1$ & PS & 7 & 57 & 36 \\
\hline $40 \cdot 1$ & PS & 0 & 57 & 43 \\
\hline
\end{tabular}

* $\mathrm{BV}=$ bacterial vaginosis; $\mathrm{CVS}=$ chorionic villous sampling; $\mathrm{NGU}=$ non-gonococcal urethritis; $\mathrm{PS}=$ previous study.

† See "Materials and methods".

$\ddagger \mathrm{P}_{4}, \mathrm{P}_{21}, \mathrm{P}_{40}=$ strain 194 subcultured 4,21 and 40 times, respectively, since isolation.

and the other two strains had a small proportion only of non-pilate organisms. Two of the strains $(40 \cdot 1$ and $67 \cdot 1)$ had had multiple subcultures and when studied previously (Johnson and Davies, 1984) were considered to be non-pilate. On reexamination, similar results were obtained in that a large proportion of non-pilate organisms was seen. A likely explanation for the difference between the expression of pili in freshly isolated and laboratory strains of G.vaginalis could be loss of pili as a result of repeated subculture. This possibility was tested by repeatedly subculturing one of the freshly isolated strains (194) of G.vaginalis. The results presented in the table show that there was an increase in the proportion of sparsely pilate organisms, although none of them lost their pili completely. Five colonies of one of the least pilate strains $(67 \cdot 1)$ were cloned and cultures on agar medium were prepared for each of them. None of these cultures comprised organisms all of which were non-pilate.
A comparison of G.vaginalis organisms grown for $24 \mathrm{~h}$ and $48 \mathrm{~h}$ and growth on human blood agar compared to that on horse blood agar did not show any difference in expression of pili. The diameter of the pili on organisms of all sixteen strains of G.vaginalis fell within the size range $(3.0-7.5 \mathrm{~nm})$ reported previously (Johnson and Davies, 1984).

\section{Discussion}

The finding that the organisms of G.vaginalis strains isolated recently were heavily pilate is in contrast to the results obtained in a previous study (Johnson and Davies, 1984) in which five of eight strains were seen to have a large proportion of nonpilate organisms and the other three strains appeared to be completely non-pilate. These were "laboratory" strains that had undergone multiple subcultures and their sparse pilation was confirmed when two of them were re-examined. It is known that some micro-organisms, for example gonococci, cease to express pili when subcultured non-selectively (Jephcott et al., 1971) and in this regard it was of interest to note that the degree of pilation of one of the G.vaginalis strains also diminished on multiple subculture. Cloning of single colonies of one of the strains which was least pilated did not result in cultures of organisms all of which were non-pilate. This suggested that loss of pili on subculture was not due to selection of organisms that were non-pilate originally but to a gradual loss of pili.

It has been shown previously that G.vaginalis is able to attach to vaginal epithelial cells in vitro (Sobel et al., 1982; Peeters and Piot, 1985) as well as to attach in vivo to produce the clue cells characteristic of bacterial vaginosis (Blackwell and Barlow, 1984). The observation that clinical isolates of G.vaginalis are highly pilate raises the question of whether the pili have a role in mediating attachment. The fact that the organisms manufacture pili suggests that they may have such a specific function. The existence of heavily and sparsely pilate strains should enable the relationship between pilation and adherence to vaginal epithelial cells to be determined and therefore help to define the role of adherence in the pathogenesis of bacterial vaginosis.

We thank Mrs H. A. Davies for her help and advice with the electronmicroscopy. Y.L.B. is in receipt of an MRC Scholarship for Training in Research Methods. 


\section{REFERENCES}

Blackwell A L, Barlow D 1984 Anaerobic vaginosis. Clinical and diagnostic aspects. In: Mårdh P-A, Taylor-Robinson $D$ (eds) Bacterial vaginosis. Almqvist and Wiksell International, Stockholm, pp 129-133.

Henrichsen J, Blom J 1975 Correlation between twitching motility and possession of polar fimbriae in Acinetobacter calcoaceticus. Acta Pathologica et Microbiologica Scandinavica 83B: 103-115.

Jephcott A E, Reyn A, Birch-Andersen A 1971 Neisseria gonorrhoeae III. Demonstration of presumed appendages to cells from different colony types. Acta Pathologica et Microbiologica Scandinavica 79B:437-439.

Johnson A P, Davies H A 1984 Demonstration by electron microscopy of pili on Gardnerella vaginalis. British Journal of Venereal Diseases 60:396-397.

Peeters M, Piot P 1985 Adhesion of Gardnerella vaginalis to vaginal epithelial cells: variables affecting adhesion and inhibition by metronidazole. Genitourinary Medicine 61: 391-395.

Sobel J D, Myers P, Levison M E, Kaye D 1982 Comparison of bacterial and fungal adherence to vaginal exfoliated epithelial cells and human vaginal epithelial tissue culture cells. Infection and Immunity 35:697-701.

Spiegel C A, Amsel R, Eschenbach D, Schoenknecht F, Holmes K K 1980 Anaerobic bacteria in nonspecific vaginitis. New England Journal of Medicine 303: 601-607.

Spiegel CA et al. 1983 Gardnerella vaginalis and anaerobic bacteria in the etiology of bacterial (nonspecific) vaginosis. Scandinavian Journal of Infectious Diseases (Suppl) 40:4146.

Taylor E, Phillips I 1983 The identification of Gardnerella vaginalis. Journal of Medical Microbiology 16: 83-92.

Totten P A, Amsel R, Hale J, Piot P, Holmes K K 1982 Selective differential human blood bilayer media for isolation of Gardnerella (Hemophilus) vaginalis. Journal of Clinical Microbiology 15:141-147. 